\title{
A disproportionate epidemic: COVID-19 cases and deaths among essential workers in
}

\section{Toronto, Canada}

Amrita Rao, ScM*,1 ${ }^{*}$, Huiting Ma, MSc ${ }^{*, 2}$, Gary Moloney, MSA ${ }^{2}$, Jeffrey C Kwong, MD, MSc ${ }^{3,4}$,

Peter Jüni, $\mathrm{MD}^{2}$, Beate Sander, $\mathrm{PhD}^{3,5,6}$, Rafal Kustra, $\mathrm{PhD}^{7}$, Stefan D Baral, $\mathrm{MD}^{1}$, Sharmistha

Mishra, MD, $\operatorname{PhD}^{2,8}$

*equal contribution / co-first authors

Affiliations: ${ }^{1}$ Department of Epidemiology, Johns Hopkins School of Public Health; ${ }^{2}$ St.

Michael' s Hospital, University of Toronto, Toronto, Canada; ${ }^{3}$ ICES, Toronto, Canada;

${ }^{4}$ Department of Family and Community Medicine, Faculty of Medicine, University of Toronto,

Toronto, Canada; ${ }^{5}$ Institute of Health Policy, Management and Evaluation, University of

Toronto, Toronto, Canada; ${ }^{6}$ Public Health Ontario, Toronto, Canada; ${ }^{7}$ Dalla Lana School of Public

Health, University of Toronto, Toronto, Canada; ${ }^{8}$ Division of Infectious Diseases, Department of

Medicine, University of Toronto, Toronto, Canada

\section{Email Addresses:}

Amrita Rao: arao24@jhu.edu

Huiting Ma: huiting.ma@unityhealth.to

Gary Moloney: gary.moloney@unityhealth.to

Jeffrey C Kwong: jeff.kwong@utoronto.ca

Peter Jüni: peter.juni@utoronto.ca 
medRxiv preprint doi: https://doi.org/10.1101/2021.02.15.21251572; this version posted March 11, 2021. The copyright holder for this preprint (which was not certified by peer review) is the author/funder, who has granted medRxiv a license to display the preprint in perpetuity. It is made available under a CC-BY-NC-ND 4.0 International license .

Beate Sander: beate.sander@uhnresearch.ca

Rafal Kustra: r.kustra@utoronto.ca

Stefan D Baral: sbaral@ihu.edu

Sharmistha Mishra: sharmistha.mishra@utoronto.ca

\section{Corresponding Author:}

Sharmistha Mishra, MD, PhD

Mailing address: Room 315, MAP Centre for Urban Health Solutions, Li Ka Shing Knowledge

Institute, 209 Victoria St., Toronto, ON Canada M5B 1T8

Email: sharmistha.mishra@utoronto.ca

Word Count: 932 
medRxiv preprint doi: https://doi.org/10.1101/2021.02.15.21251572; this version posted March 11, 2021. The copyright holder for this preprint (which was not certified by peer review) is the author/funder, who has granted medRxiv a license to display the preprint in perpetuity. It is made available under a CC-BY-NC-ND 4.0 International license.

\section{List of Abbreviations}

$\mathrm{CCM}+$ : Case and Contact Management Solutions

DA: dissemination areas

IQR: interquartile range 
medRxiv preprint doi: https://doi.org/10.1101/2021.02.15.21251572; this version posted March 11, 2021. The copyright holder for this preprint (which was not certified by peer review) is the author/funder, who has granted medRxiv a license to display the preprint in perpetuity.

It is made available under a CC-BY-NC-ND 4.0 International license .

\begin{abstract}
Shelter-in-place mandates and closure of non-essential businesses have been central to COVID19 response strategies including in Toronto, Canada. Approximately half of the working population in Canada are employed in occupations that do not allow for remote work suggesting potentially limited impact of some of the strategies proposed to mitigate COVID-19 acquisition and onward transmission risks and associated morbidity and mortality. We compared per-capita rates of COVID-19 cases and deaths from January 23, 2020 to January 24, 2021, across neighborhoods in Toronto by proportion of the population working in essential services. We used person-level data on laboratory-confirmed COVID-19 community cases $(\mathrm{N}=74,477)$ and deaths $(\mathrm{N}=2319)$, and census data for neighborhood-level attributes. Cumulative per-capita rates of COVID-19 cases and deaths were 3-fold and 2.5-fold higher, respectively, in neighborhoods with the highest versus lowest concentration of essential workers. Findings suggest that the population who continued to serve the essential needs of society throughout COVID-19 shouldered a disproportionate burden of transmission and deaths. Taken together, results signal the need for active intervention strategies to complement restrictive measures to optimize both the equity and effectiveness of COVID-19 responses.
\end{abstract}


medRxiv preprint doi: https://doi.org/10.1101/2021.02.15.21251572; this version posted March 11, 2021. The copyright holder for this preprint (which was not certified by peer review) is the author/funder, who has granted medRxiv a license to display the preprint in perpetuity.

It is made available under a CC-BY-NC-ND 4.0 International license .

\section{Background}

The City of Toronto, Canada's largest city, has reported 92,644 cases and 2,619 deaths from COVID as of February 23, 2021.(1) In addition to testing and isolation, shelter-in-place mandates and the closure of non-essential businesses aiming to reduce contacts have been central to Toronto's COVID-19 response. However, many businesses and services have been deemed essential to support the general needs of society. Specifically, Public Safety Canada defines "essential workers" as working in one of ten critical infrastructure sectors, including health, food, transportation, and manufacturing.(2) As of April 2020, an estimated $40 \%$ of the working population in Canada were essential workers employed in occupations not amenable to remote work, with the lowest likelihood of remote work among lower income households.(3) Thus, it has been suggested that shelter-in-place mandates may be insufficient at protecting essential workers from COVID-19 and associated morbidity and mortality. In this study, we evaluated the relationship between per-capita rates of COVID-19 cases and deaths and the proportion of the population working in essential services across neighborhoods in Toronto, Canada.

\section{Methods}

We used Case and Contact Management Solutions (CCM)+ person-level data on laboratoryconfirmed COVID-19 cases and deaths, and the Statistics Canada 2016 Census data for neighborhood-level attributes. The study population comprised community cases and deaths, thus excluding long-term care residents, reported between January 23, 2020 and January 24, 2021 in Toronto. Toronto has a population $2,731,571$ including $51.5 \%$ who self-identify as 
medRxiv preprint doi: https://doi.org/10.1101/2021.02.15.21251572; this version posted March 11, 2021. The copyright holder for this preprint (which was not certified by peer review) is the author/funder, who has granted medRxiv a license to display the preprint in perpetuity.

It is made available under a CC-BY-NC-ND 4.0 International license .

visible minority. We stratified the city's 3702 dissemination areas (DA) representing geographic areas including approximately $400-700$ individuals into tertiles by ranking the proportion of population in each DA working in essential services (health, trades, transport, equipment, manufacturing, utilities, sales, services, agriculture). Strata 1, 2, and 3 comprised DAs across which a median of $27.8 \%$ (inter-quartile range [IQR] 23.4-31.5\%), 44.7\% (IQR 40.0\%-50.0\%), and 62.9\% (IQR 58.4\%-68.0\%) of the population, respectively, worked in essential services. We generated per-capita daily epidemic curves using 7-days rolling averages for cases and for deaths, and cumulative per-capita rates using census-reported population of each DA. The date of report to public health for both COVID-19 cases and deaths were used for per-capita rate calculations.

\section{Findings}

COVID-19 was initially concentrated in stratum 1 (lowest essential workers). By early April, percapita cases were consistently higher in strata 2 and 3 (Figure 1A), and persisted during each period of closure of non-essential services (first lockdown March 17 to May 18, second major restriction November 23 to December 25, and a more stringent lockdown starting on December 26). By the end of the study period, cumulative rates of cases per 100,000 were 1332,2495 , and 4355 in strata 1, 2, and 3, respectively; representing a 1.9-fold and 3.3-fold higher rate than stratum 1 (Figures 1C \& D).

Per-capita COVID-19 deaths were similarly concentrated in strata 2 and 3. By the end of the study period (Figure 1B), cumulative rates of death per 100,000 in strata 1, 2, and 3 were 49, 
medRxiv preprint doi: https://doi.org/10.1101/2021.02.15.21251572; this version posted March 11, 2021. The copyright holder for this preprint (which was not certified by peer review) is the author/funder, who has granted medRxiv a license to display the preprint in perpetuity.

It is made available under a CC-BY-NC-ND 4.0 International license .

81 , and 123 , respectively, representing a 1.9 -fold and 2.5 -fold higher rate than stratum 1

(Figures 1C \& D). The number of daily per capita cases among stratum 2 was consistently

between strata 1 and 3. Daily per-capita deaths fluctuated over the course of the outbreak, demonstrating similarities with stratum 3 during the first lockdown and with stratum 1 during the second major restriction.

\section{Discussion}

In the context of shelter-in-place mandates, there have been disproportionate risks and consequences of COVID-19 borne by those living in neighborhoods with higher proportions of essential workers. The results presented here are consistent with early studies highlighting that these occupations would not be amenable to remote work, and thus people may experience sustained contact rates irrespective of restrictive measures.(3) Many of these occupations afford lower wages and are often held by people hired as contractors with unclear labor rights and generally lacking traditional employment benefits, such as paid sick leave.(4-6) Precarious financial conditions among many essential workers further limit bargaining power to demand adequate personal protective equipment and safe working conditions from employers or clients. $(7,8)$ Decreased beneficial impact of restrictive COVID-19 mitigation strategies is likely compounded by increased likelihood that lower income essential workers also live in multigenerational households, where an older parent or grandparent may be at a much higher risk of morbidity or mortality.(4) 
medRxiv preprint doi: https://doi.org/10.1101/2021.02.15.21251572; this version posted March 11, 2021. The copyright holder for this preprint (which was not certified by peer review) is the author/funder, who has granted medRxiv a license to display the preprint in perpetuity.

It is made available under a CC-BY-NC-ND 4.0 International license .

The findings highlight a prevention gap with restrictive COVID-19 intervention strategies including shelter-in-place mandates. Moving forward necessitates policies and programs that actively protect workers in occupations that remain active in the context of lockdowns. Public and occupational health strategies could include primordial prevention aimed at keeping COVID-19 out of essential workplaces including through paid leave facilitating people to stay home if they have symptoms or a known exposure; primary prevention designed to limit transmission within the workplace such as onsite rapid testing and improved access to symptom assessments, and improved ventilation; secondary prevention directed at limiting the size of the outbreak including infection prevention and control measures including isolation, mass testing, and cohorting; and tertiary prevention strategies targeted at limiting outbreakrelated mortality including temporary housing support to prevent transmission to households of essential workers.(9) Moreover, these data support the specific allocation of COVID-19 vaccines to particularly burdened communities with more essential workers given the intersection of higher occupational and housing risks in these areas.

In sum, these are data from a large urban center demonstrating that the communities with more essential workers who continued serving the needs of society during COVID-19 have been disproportionately affected by COVID-19 morbidity and mortality. Ultimately, these results suggest the need for active public and occupational health intervention strategies to complement restrictive measures to optimize both the equity and effectiveness of COVID-19 responses. 
medRxiv preprint doi: https://doi.org/10.1101/2021.02.15.21251572; this version posted March 11, 2021. The copyright holder for this preprint (which was not certified by peer review) is the author/funder, who has granted medRxiv a license to display the preprint in perpetuity. It is made available under a CC-BY-NC-ND 4.0 International license.

\section{Ethics Approval}

The University of Toronto Health Sciences Research Ethics Board (protocol no. 39253) approved the study.

\section{Acknowledgements}

Reported COVID-19 cases were obtained from the Contact Management Solutions (CCM)+ via the Ontario COVID-19 Modelling Consensus Table and Ontario Ministry of Health. We thank Kristy Yiu (MAP Centre for Urban Health Solutions, St. Michael's Hospital) for support with data management, and the Ontario Community Health Profiles Partnership.

\section{Funding}

This work was supported by the Canadian Institutes of Health Research (grant no. VR5-172683). 
medRxiv preprint doi: https://doi.org/10.1101/2021.02.15.21251572; this version posted March 11, 2021. The copyright holder for this preprint (which was not certified by peer review) is the author/funder, who has granted medRxiv a license to display the preprint in perpetuity.

It is made available under a CC-BY-NC-ND 4.0 International license .

\section{References}

Website

1. City of Toronto. COVID-19: Status of Cases in Toronto [Internet]. 2021. Available from: https://www.toronto.ca/home/covid-19/covid-19-latest-city-of-toronto-news/covid-19-statusof-cases-in-toronto/.

2. Public Safety Canada. Guidance on Essential Services and Functions in Canada During the COVID-19 Pandemic [Internet]. 2021. Available from:

https://www.publicsafety.gc.ca/cnt/ntnl-scrt/crtcl-nfrstrctr/esf-sfe-en.aspx.

3. Deng Z, Messacar D, Morissette R. Running the economy remotely: Potential for working from home during and after COVID-19. 2020;STATCAN COVID-19; Data to Insights for a Better Canada, no. 00026.

5. Henderson J. Health workers forced to quarantine without pay, Canadian union says 2021 [updated 2021 Jan 20]. Available from:

https://www.medpagetoday.com/hospitalbasedmedicine/workforce/90801.

Report

4. Tomer A, Kane JW. To protect frontline workers during and after COVID-19, we must define who they are. Brookings; 2020. 2020 Jun 10.

8. O'Donnell J. Essential workers during COVID-19: At risk and lacking union

representation. Brookings; 2020. 2020 Sep 3.

Journal Article

6. Pichler S, Wen K, Ziebarth NR. COVID-19 emergency sick leave has helped flatten the curve in the United States. Health Affairs. 2020;39(12).

Newspaper Article

7. Jones RP. Federal sickness benefit falls short of paid sick leave protections, advocates say. CBC. 2021. 2021 Jan 14.

\section{Book Section}

9. Kisling LA, Das JM. Prevention strategies. StatPearls [Internet]. Treasure Island (FL): StatPearls Publishing; 2020. 
medRxiv preprint doi: https://doi.org/10.1101/2021.02.15.21251572; this version posted March 11, 2021. The copyright holder for this preprint (which was not certified by peer review) is the author/funder, who has granted medRxiv a license to display the preprint in perpetuity.

\section{Figure Legend}

Figure 1. Daily per-capita COVID-19 cases (A) and deaths (B) and cumulative per-capita COVID-19 cases (C) and deaths (D) by neighbourhood-level proportion of essential workers in Toronto, Canada (January 23, 2020 to January 24, 2021). The daily per-capita rate is depicted as a 7-day rolling average. Stratum 1 represents neighbourhoods with the smallest proportion of the population working in essential services, while stratum 3 represents neighbourhoods with the highest proportion of essential workers. Cases and deaths do not include residents of long-term care homes. Essential services include: health, trades, transport, equipment, manufacturing, utilities, sales, services, and agriculture. Closure of non-essential workplaces are indicated by: (a) from the start of the first lockdown on March 17, 2020 to (b) the re-opening of the province on May 18, 2020; (c) the start of the $2^{\text {nd }}$-major restriction on November 23; and (d) the start of a more stringent lockdown on December 26, 2020. By the end of the study period, cumulative rates of cases per 100,000 population were 1332,2495 , and 4355 in strata 1,2 , and 3, respectively; and cumulative rates of COVID-19 deaths per 100,000 population were 49,81 , and 123 in strata 1, 2, and 3, respectively. 
Figure 1.

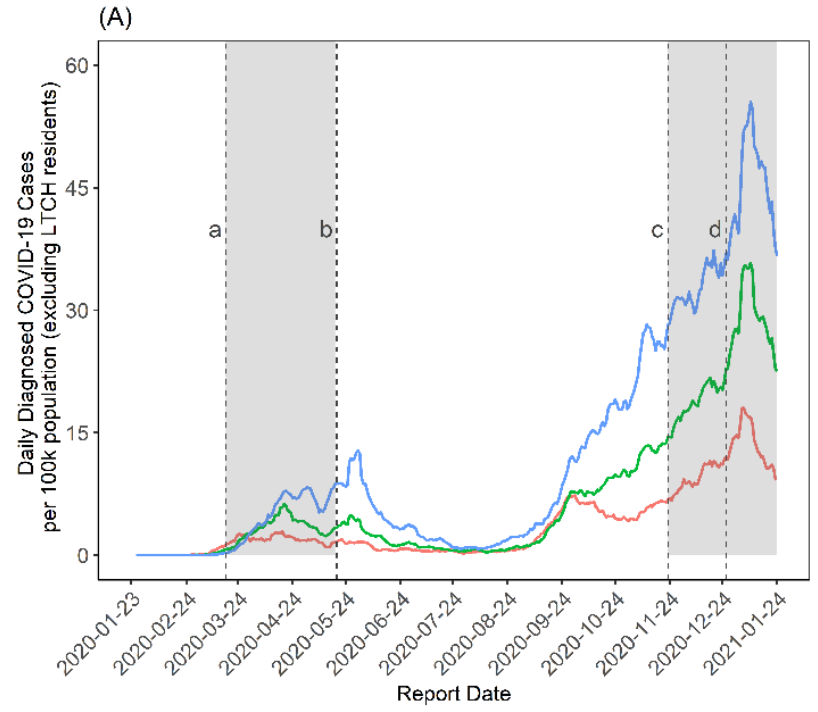

Median (IQR) Proportion Essential Workers

$1=27.8 \%(23.4-31.5)-2=44.7 \%(400-500)-3=62.9 \%(58.4-68.0)$

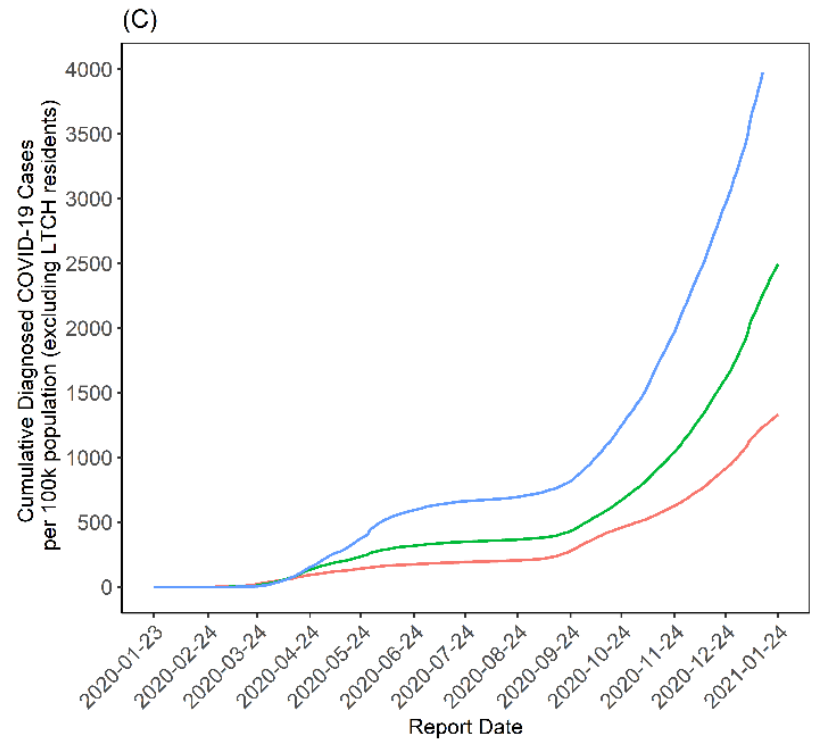

$-1=27.8 \%(23.4-31.5)-2=44.7 \%(40.0-50.0)-3=62.9 \%(58.4-68.0$

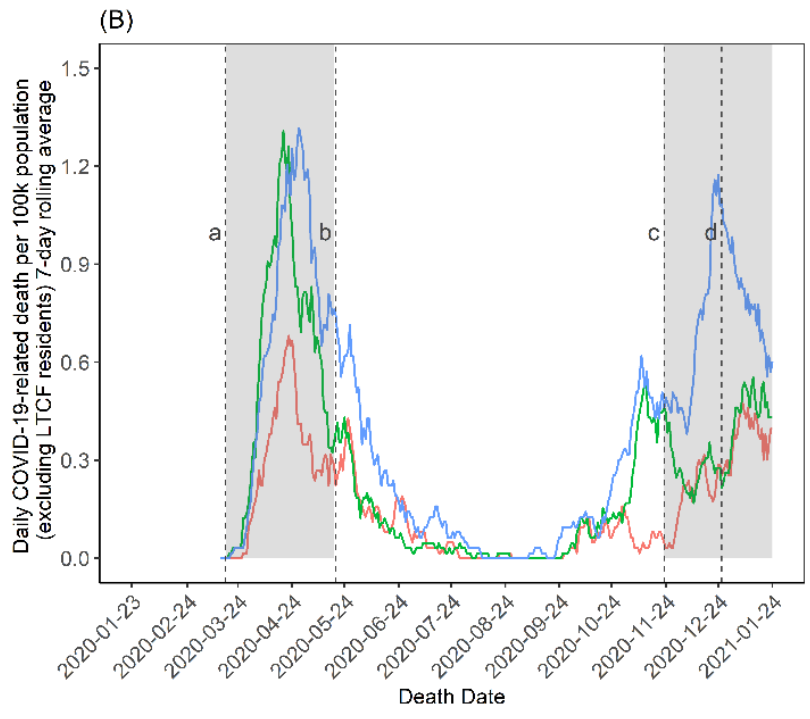

Median (IQR) Proportion Essential Workers

$1=27.8 \%(23.4-31.5)-2=44.7 \%(40.0-50.0)-3=62.9 \%(58.4-68.0)$

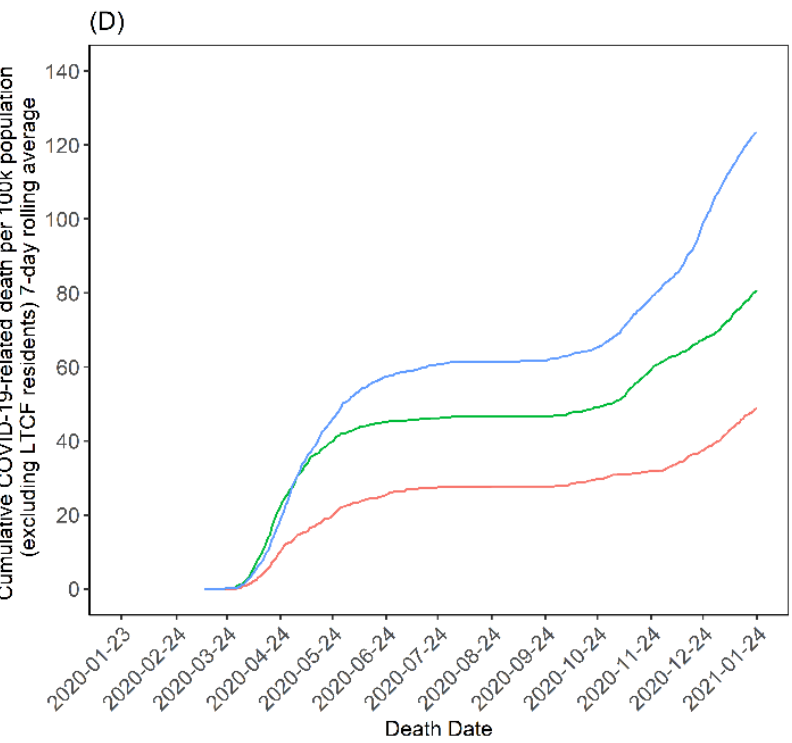

$-1=27.8 \%(23.4-31.5)-2=44.7 \%(40.0-50.0)-3=62.9 \%(58.4-68.0)$ 